\section{Weather wise}

from Vera Rich

THE recent talks in Geneva between Soviet and US delegations on the banning of climatic manipulation for military purposes has focused attention, once again, on the draft convention dealing with weather warfare which the Soviet Union presented to the United Nations last autumn, and which, at the time, was viewed in many quarters as little more than a kind of appendix to a general concern with problems of the environment

Russia has, of course, a long history of climatic warfare, and her secret allies 'General January' and 'FieldMarshal February' have, through the ages, proved the downfall of Swedes, Poles, French and Germans. In a situation of conventional warfare, the Russian army has only to retreat sufficiently far and sufficiently slowly for the invader to be trapped by winter - and the climate does the rest. But, endowed as she is with a natural strategic weather advantage, the Soviet Union has been quick to see the possibilities of artificial climatic manipulation. Recent articles in Mezhdunarodmaya Zhizn' and Krasnaya Zvezda have drawn attention to a number of possible artificial meteorological weapons, ranging from the melting of the Arctic ice and tsunami (tidal waves) caused by nuclear explosions on the edge of the continental shelf to the use of infrasound and atmospheric activity to produce psychotropic effects-depression, terror, and the "suppression of mental activity"-in large groups of the enemy in specific target areas. According to the articles in Mezhdunarodmaya Zhizn', the Americans are researching the possibility of "changing the nature of lightning", with a view to being able to direct electrical charges of "tremendous" power against specific targets.

It would be interesting to know the source of this last piece of information. When Academician Kirillin, the Soviet Minister of Power, visited Britain in May 1974, he was shown an impressive experiment at the Culham Atomic Energy Research Establishment in which lightning striking an aircraft in flight was simulated. Could this have been interpreted as a front for some sinister NATO-and therefore, in Soviet eyes, American-weapon?

Some of the other potential weapons detailed in the Soviet press verge on the fantastic - a localised window in the ozone layer to admit ultraviolet radiation, for example-and it seems difficult to see why $\mathrm{Mr}$ Brezhnev has found it necessary to stress the urgency of new agreements banning development in this field. Perhaps the urgency is more a matter of politics than immediate military danger. As a preliminary to the projected Ford-Brezhnev summit meeting, it would be gratifying if the USA and the USSR could reach some form of international agreement in the cause of peace and friendship. And what could be easier than for both sides to renounce the use of a weapon that neither actually possesses at the present time.

\section{THEOLOGY was once known as}

"the queen of the sciences", and although an examination of recent Nature indexes does not produce many references to this subject, I think it may be permissible to mention the idea of the "God of the gaps". I have unfortunately been unable to trace the origin of this phrase, which is used to describe the views of those who are unable to come out clearly as rationalistic atheists. They hang on to the idea of a deity, but nestrict his activities to the gaps between the major fields of man's activities, where science is thought to be able to give a full explanation.

My interest in this theological proposition was aroused when I realised that it was very similar to the view held by many leading conservationists. They say that they believe that wildlife and countryside preservation is important, but they acknowledge that the interests of the farmer and of food production must have priority in any scheme for managing the rural landscape. This point is explicit in the recent report of the Countryside Commission, New Agricultural Landscapes. Any wish to retain the familiar pattern of hedgerows, picturesque buildings and flowerrich though rather unproductive trees and, and these are planted with meadows is castigated as sentimental. reserves.

We are urged to try to make the best All these developments result, howof the inevitable.

It must be admitted that, even within landscape and a reduction in numbers this pattern of farming development, of many native plants and animals. useful compromises which have done This is accepted because of the belief much to spare wildlife (particularly that we must do everything possible to birds) have been possible. There have maximise food production, as otherwise now been many 'Silsoe-type' exercises, we may all face malnutrition at the for example. These follow the pattern best and mass starvation at the worst.
A country like Britain that imports nearly half its food cannot enjoy the luxury of 'wasting' any area for conservation if it can be used for food production.

I believe that the time has come for conservationists to be much more aggressive. Farmers have a right to make a reasonably good living from what may be a very difficult and exhausting job. The government has the duty to see that Britain's food supply is safeguarded, even if the pound sterling falls in value so that we cannot continue to import so much of what we eat. There is a good chance that in a few years the growing world population will absorb any surpluses, and that we will be unable to make good food deficiencies by imports. All these points are taken as arguments in favour of maximising productivity and treating conservation with caution.

I do not believe. however, that the choice is really between the risk of starvation with a rich and varied countryside, and enough food with an impoverished landscape. Britain already produces enough food to provide its population with an adequate diet, with enough calories and protein for all. Imports are mainly used to feed livestock to provide meat, which is produced for enjoyment rather than to prevent any malnutrition. The choice is really between two forms of enjoyment - a meat-rich diet or a countryside rich in wildlife. So the conservationist need no longer be content with the gaps-he can come out in to the open and rightly demand his share in shaping the future pattern of all parts of the rural landscape. 